\title{
Relevance of Accreditation Rating With Achievement of School Performance at State Elementary School in Subulussalam Aceh Province
}

\author{
Ade Amriani ${ }^{1)}$ \\ State Elementary School's Teacher 7 \\ Subulussalam, Aceh, Indonesia \\ adeamriani82@gmail.com
}

\author{
Sukarman Purba ${ }^{2)}$ \\ Lecturer at State University of \\ Medan,North Sumatra, Indonesia
}

\author{
Darwin $^{3)}$ \\ Lecturer at State University of \\ Medan,North Sumatra, Indonesia
}

\begin{abstract}
- this study aims to find out (1) the relevance of accreditation ratings with elementary school performance achievements (2) the level of quality of primary schools based on accreditation ratings. This study uses descriptive analysis research method with a quantitative approach. The population in this study were 78 State Primary Schools (SD) in Subulussalam City, and classified according to accreditation ratings, then used area sampling techniques. Furthermore, the analysis technique used is descriptive analysis techniques and correlation analysis techniques. The results showed that there was a relationship between school accreditation status and school achievement performance. Public elementary schools in the Subulusalam city with A accreditation has much better quality than $B$ accreditation, and $\mathrm{C}$ accreditation. And schools quality of primary with $B$ accreditation is much better than $C$ accreditation. Achievement of better school performance is based on the extent to which schools meet 8 national education standards.
\end{abstract}

Keywords - school accreditation; accreditation ranking; school performance

\section{INTRODUCTION}

The objectives of holding school / Madrasah accreditation activities are: (1) providing information about the feasibility of schools / Madrasahs or programs implemented based on National Education Standards. (2) Providing recognition of feasibility ratings. (3) Providing recommendations on education quality assurance to programs and or accredited education units and related parties.

School/Madrasah National Accreditation Board or in Indonesia called as Badan Akreditasi Nasional Sekolah (BAN$\mathrm{S} / \mathrm{M})$ states that the implementation of school/Madrasah accreditation has the following benefits: (1) can be used as a reference in efforts to improve the quality of schools / Madrasahs and plans for school / Madrasah development. (2) Can be used as a motivator so that Schools/Madrasahs continue to improve the quality of education in a gradual, planned, and competitive manner at the district / city, provincial, national and even regional and international levels. (3) Can be used as feedback in efforts to empower and develop the performance of school / Madrasah citizens in order to implement the vision, mission, goals, objectives, strategies and programs of schools / Madrasahs. (4) Assist in identifying Schools / Madrasahs and programs in the context of providing government assistance, investment in private funds and donors or other forms of assistance. (5) Material information for Schools / Madrasahs as learning communities to increase support from the government, the community, and the private sector in terms of professionalism, morals, labor and funds. (6) Assisting Schools / Madrasahs in determining and facilitating the transfer of students from one school to another, teacher exchanges and mutually beneficial cooperation.

National School Acreditation Department (2017) states that the school accreditation rank consists of three classifications as follows: A (Very good), B (Good), and C (Enough). For schools whose accreditation results are less than $\mathrm{C}$, are declared not accredited.

In accordance with the guidebook for the National School / Madrasah Accreditation Agency on Changes in Device Accreditation in 2017, the criteria for accredited status are Schools / Madrasahs if: first, getting the final score from at least 71 accreditation results, second, Obtaining standard components of facilities and infrastructure not less than 61 , next, There is no standard component value below 50, and the last Schools / Madrasahs are declared not accredited if the school / Madrasah does not meet points first, second and third.

Likewise, the [1] atthor said that ranks accreditation results if the accreditation results meet the criteria for accreditation /Madrasah status accredited to obtain the following accreditation ratings: first, accreditation rating (superior) if schools / Madrasahs get Accreditation (NA) scores of 91 to 100 (91 $91 \mathrm{NA} \leq 100$ ); second Rating of Accreditation B (Good) if the school / Madrasah receives Accreditation (NA) value of $(81 \leq \mathrm{NA} \leq 90)$; third $\mathrm{C}$ Accreditation Rating (Sufficient) if the school / Madrasah obtains an Accreditation (NA) value of $(71 \leq \mathrm{NA} \leq 80)$ and forth Schools that are not accredited are schools / Madrasahs that receive grades which has two categories, are 61 to $70(61 \leq \mathrm{NA} \leq 70)$ with $\mathrm{D}$ accreditation (Less) and 0 to $60(0 \leq \mathrm{NA} \leq 60)$ with an accreditation rating of $\mathrm{E}$ (Very Less) 
The impact of the accreditation value for school / Madrasah management is the result of accreditation is expected to be an information material to map school / Madrasah eligibility indicators, school / Madrasah performance, including the performance of principals / Madrasah during their leadership. In addition, the results of management accreditation are also needed school / Madrasah as input for school / Madrasah programs and spending and spending.

The quality of schools must have at least 15 (fifteen) characteristics [2] as follows: Performance; related to the functional aspects of the school. Lines time: finish with a reasonable time. Reliability; the age of excellent service lasts a long time. Durability: durability, Beautiful (acetates), Human relations (personal interface): upholding moral values and professionalism. Easy to use, facilities and infrastructure are used. Special features of certain advantages. Certain standards; meet certain standards. Constant, constant, or stable consistency, Uniformity: without variation, not mixed. Able to serve (serviceability): able to provide the best service. And Accuracy in services.

In the relationship between superior and quality schools, [2] states that superior quality schools have 3 (three) types, namely:

Type 1. In this type where the school accepts and chooses students who will enter the criteria of having high academic achievement. Although the teaching and learning process in schools is not extraordinary and even tends to be orthodox, it can be ascertained that because it has superior input, the output produced is also superior.

Type 2. In this type, by offering complete and luxurious facilities that are redeemed by higher education tuition (SPP), and indeed this school was built to stem the flow of Indonesians coming to foreign schools or international schools domiciled in the country. High academic achievement is automatically not a reference input received in this type of school, but this school usually relies on a number of "learning" learning patterns by carrying a particular theoretical approach as its appeal. So that the resulting output can be as promised.

Type 3 . In this type, quality schools emphasize a positive learning climate in the school environment. Accept and be able to process students who enter low-performance schools into high-quality output.

Based on a survey carried out at the Subulusalam Education Office Sub-Office of Education, and some Primary Schools on January 22, 2018 to February 2, 2018, there is an impression that accreditation is carried out by Provincial Accreditation Agencies Schools / Madrasahs, especially in the Sumbulussalam is only an administrative activity. Sheer and not educating. The results of school accreditation which should describe the quality of schools have not received a positive response from the local government so that it is impressed that the results of accreditation have no effect on education policies, especially those related to the appreciation of the careers of teachers, principals and the provision of assistance to schools which are actually good accreditation results.

The following is a presentation of the survey as preliminary data on the number of primary / equivalent schools in Subulusalam City, an accredited and unaccredited Aceh Province.

To get an overview of the percentage of elementary school accreditation in Sumbulussalam, a clearer visual can be seen in Fig 1.

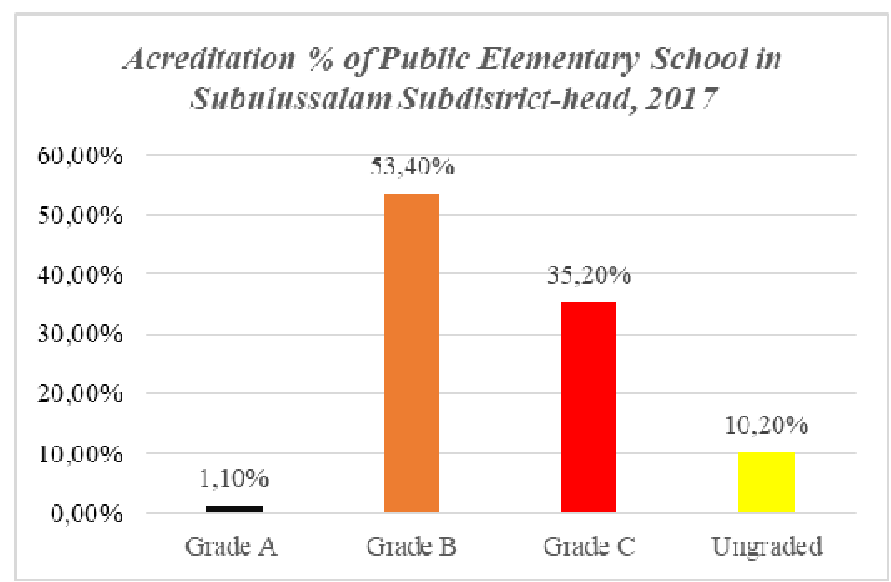

Note: Public Elementary School: 83, Madrasah Ibitidaiyah: 5

Fig 1. Percentage of SD / MI Accreditation in Subulusalam City in 2017

Fig. 1 shows that out of 88 (eighty eight) Public Elementary Schools and Islamic Primary Schools in Subulusalam City, 79 (seventy nine) schools have been accredited meaning that there are only $10.2 \%$ of schools that have not been accredited, namely 9 (nine) schools. The accreditation results are, from 79 schools that are accredited there are only 1 (one) accredited school with A results, meaning there are only $1.1 \%$ of 88 schools that have the best accreditation and the rest are accredited with B results with 53.4\% achievement, and $\mathrm{C}$ with $35.2 \%$ achievement.

Noting the phenomenon of the development of school accreditation ratings, it is necessary to study the relevance of accreditation ratings with the achievement of school performance through research in the form of this thesis.

\section{LITERASI RIVIEW}

\section{A. The Nature of Primary School Accreditation}

School accreditation is an assessment activity carried out by the government and / or an independent institution that is authorized to determine the appropriateness of education programs and / or units on formal and non-formal education pathways at all levels and types of education, based on established criteria, as a form of public accountability conducted in an objective, fair, transparent and comprehensive 
manner using instruments and criteria that refer to the National Education Standards [3].

In the school / Madrasah accreditation guidebook, accreditation is interpreted as a qualification assessment process using established and open quality standard criteria. If the process of assessing the quality of primary schools, both public and private primary schools by using the quality standard criteria set by the government or accreditation institution, the results of the research are then used as the basis for maintaining and improving the quality of the organization and service of the institution concerned [3]

\section{B. Purpose and Benefits of School Accreditation}

Based on the book Analysis Study of the School / Madrasah Accreditation System published by the Ministry of National Education [3] are: Provide information about the feasibility of the school / Madrasah or the program implemented based on the National Education Standards. Provides recognition of feasibility ratings. Provide recommendations regarding education quality assurance to programs and or accredited education units and related parties. To obtain an overview of the state of Madrasah performance and to determine the level of feasibility of a Madrasah in carrying out education. As a basis that can be used as a tool for guidance and development in order to improve the quality of education in Madrasahs.

\section{Requirements for School Accreditation}

Schools can take part in accreditation activities, if they meet the following requirements, they are; Having a Madrasah Establishment / Operational Decree, Having students at all grade levels, have educational facilities and infrastructure. Have educators and education personnel. Implementing the applicable curriculum, and having completed students.

\section{Components assessed in School Accreditation}

In the implementation of elementary school accreditation must include eight components in the National Education Standards, namely:

Content Standard, (Minitstry of Education No. 22/2006), Process Standards, (Ministry of Education No. 41/2007), Graduates Competency Standards, (Ministry of Education No. 23/2006), Standards of Educators and Education Personnel, (Minister of National Education Regulation No. 13/2007 e. Standards of Facilities and Infrastructure (Ministry of Education No. 24/2007), Management Standards, (Ministry of Education No 19/2007), Financing Standards, (Government Regulation 48/2008), Educational Assessment Standards. (Ministry of Education No 20/2007)

\section{E. The Nature of School Performance}

In general, the notion of performance is a quantitative measure that describes the level of achievement of a predetermined goal or goal by taking into account indicators of input, process, and output. Furthermore, other experts say that performance is a combination or combination of motivation that exists in a person and his ability to carry out a job [4] In relation to institutions, including schools, performance is the work that can be achieved by all school members in the institution with the authority and responsibility to achieve institutional goals (schools). Assessment is carried out through a series of activities in the process of comparing school conditions with the criteria (standards) that have been set.

These standards include: a) standard input, b) process standards, and c) output standards. Input standards include: a) aspects of education personnel, b) aspects of student affairs, and c) aspects of facilities and d) financing. Process standards include: a) aspects of curriculum and teaching materials, b) aspects of PBM, c) aspects of assessment, and d) aspects of management and leadership. While the output aspects include: a) aspects of student learning achievement, b) aspects of teacher and principal achievement, and c) aspects of school achievement. In terms of process, aspects of the curriculum and teaching materials consist of: curriculum, teaching materials, and student books.

The existence of these three indicators is quite important, because without a clear curriculum, comprehensive teaching materials and supporting books for students that support the curriculum, the learning process will not work effectively. In terms of output, aspects of student learning achievement consist of: academic, non-academic, and personality. Student achievement becomes the main benchmark in seeing the success of education in general.

\section{F. School Performance Assessment Function}

Performance appraisal is carried out using a comprehensive instrument and is developed based on the established quality standards, the results of the assessment are expected to map in a comprehensive and comprehensive school profile. Therefore the function of the assessment system, namely:

a. In terms of knowledge, namely as information for all parties regarding school feasibility and performance seen from various related elements, referring to the standards set along with aspects as well as indicators.

b. In terms of accountability, namely as a form of school accountability to the community, whether the services carried out and provided by the school have met the expectations or desires of the community.

c. In terms of coaching and development, namely as a basis for schools, governments, and communities in an effort to improve or develop school quality.

The terms of reference used in developing instruments use patterns: input - process - output. The input, process and subsequent output in the development of this instrument are called components. Sub-components are then called aspects, and part of the aspect is an indicator. For more details the relationship between components, aspects, and indicators can be seen in Table1. 


\section{G. Relevance of School Accreditation to school performance indicators}

Accreditation is carried out through the following procedures: (a) application for accreditation from the school; (b) self-evaluation by the school; (c) processing the results of self-evaluation; (d) visitation by assessors; (e) determination of the results of accreditation; (f) issuance of accreditation certificates and reports. Then there is a very close relationship between the implementation of school accreditation and efforts to improve school performance. Schools that will be accredited, all the components involved, both principals, teachers, administrative staff, school committees, students and other stakeholders must truly cooperate and improve their performance in accordance with their respective duties and functions. If every component involved works according to and meets the accreditation instrument, there will be an increase in the performance of the school.

TABLE.1. Relationship between Components, Aspects, and School Performance Indicators

\begin{tabular}{|c|c|c|c|}
\hline No & Components & Aspect & Indicator \\
\hline \multirow{4}{*}{1} & \multirow{4}{*}{ Input } & Teachers & $\begin{array}{l}\text { - Teacher } \\
\text { - Headmaster } \\
\text { - Employee }\end{array}$ \\
\hline & & Students & $\begin{array}{l}\text { - Student Condition of } \\
\text { students } \\
\text { - Student achievement }\end{array}$ \\
\hline & & $\begin{array}{l}\text { Tools And } \\
\text { Finance }\end{array}$ & $\begin{array}{l}\text { - Classrooms } \\
\text { - Laboratory } \\
\text { - Library } \\
\text { - Principal's office } \\
\text { - Skill Room / } \\
\text { - Art / computer } \\
\text { - Administration room } \\
\text { - Restroom } \\
\text { - School environment } \\
\text { - Supporting facilities } \\
\text { - Financing }\end{array}$ \\
\hline & & Financial & $\begin{array}{l}\text { - Facilities and Financing } \\
\text { - Funding Financing } \\
\text { - Use of funds }\end{array}$ \\
\hline \multirow{3}{*}{2} & \multirow{3}{*}{ Process } & $\begin{array}{l}\text { Curriculum } \\
\text { and teaching } \\
\text { material } \\
\text { processes }\end{array}$ & $\begin{array}{l}\text { - curriculum } \\
\text { - Teaching materials } \\
\text { - Student book } \\
\text { - Class management } \\
\text { - Teaching Methodology } \\
\text { - Use of learning media }\end{array}$ \\
\hline & & $\begin{array}{c}\text { Teaching } \\
\text { process }\end{array}$ & $\begin{array}{l}\text { - Teacher readiness } \\
\text { assessment } \\
\text { - Assessment } \\
\text { Implementation } \\
\end{array}$ \\
\hline & & Management & $\begin{array}{l}\text { - Planning } \\
\text { - Program implementation } \\
\text { - Supervision } \\
\text { - Leadership } \\
\end{array}$ \\
\hline \multirow[t]{2}{*}{3} & \multirow[t]{2}{*}{ Output } & $\begin{array}{c}\text { Students } \\
\text { Achievement }\end{array}$ & $\begin{array}{l}\text { - Academic } \\
\text { - Non-Academic } \\
\text { - Personality } \\
\end{array}$ \\
\hline & & $\begin{array}{c}\text { Teachers } \\
\text { Acievement }\end{array}$ & $\begin{array}{l}\text { - Teacher achievement } \\
\text { - Principal achievement }\end{array}$ \\
\hline
\end{tabular}

\begin{tabular}{|l|l|l|}
\hline & $\begin{array}{c}\text { Schools } \\
\text { Achievement }\end{array}$ & $\begin{array}{l}\bullet \text { Academic school } \\
\text { achievement } \\
\bullet \text { Non-Academic }\end{array}$ \\
\hline
\end{tabular}

\section{H. Impact of School Accreditation in Improving School Performance}

The first impact of school acreditation rating is growing awareness of school residents to improve performance in accordance with their respective duties and functions as principals, teachers, TU staff, students and school committees.

Next, growing awareness of school residents to provide and improve services in accordance with the criteria set out in the accreditation process.

Then, growing awareness of cooperating with all school components to get the best assessment related to the results of accreditation.

After that knowing the shortcomings that the school has as a material for future improvement and school development.

The growing awareness of improving the quality of education through the attainment of established standards.

And last impact is growing pride of all school citizens and maintaining the results of accreditation if they have obtained the best such as being accredited A.

\section{METHODOLOGY}

The method used in this study is quantitative research using non-experimental research that is correlational in nature. This study revealed two types of variables as references for research, namely the variable (X) related to the school accreditation status and the dependent variable (Y) which is about the quality of schools. The population in this study was 78 schools. The sampling technique in this study uses a sampling area technique, with a total sample of 11 elementary schools. The research instrument uses documents in the form of accreditation certificates for school accreditation status variables and closed questionnaires for school quality variables. The data analysis of this study uses descriptive analysis techniques and correlation techniques because the data in variable $(\mathrm{X})$ school accreditation status is ordinal data, while data in variable (Y) school quality is ordinal data that is converted into interval data

The analysis process are: data reduction, data display, and conclusion drawing/verification Test credibility is done by triangulation.

\section{RESULTS AND DISCUSSION}

\section{A. Result}

Based on the results of the descriptive analysis, it can be seen that out of the 11 schools studied the number of schools with A accreditation status was 1 school or $9 \%$. The number of schools with B accreditation status is 5 schools or $45.5 \%$. Furthermore, the number of schools with $\mathrm{C}$ accreditation status is 5 schools or $45.5 \%$. Overview of research results as visualized in Fig 2. 


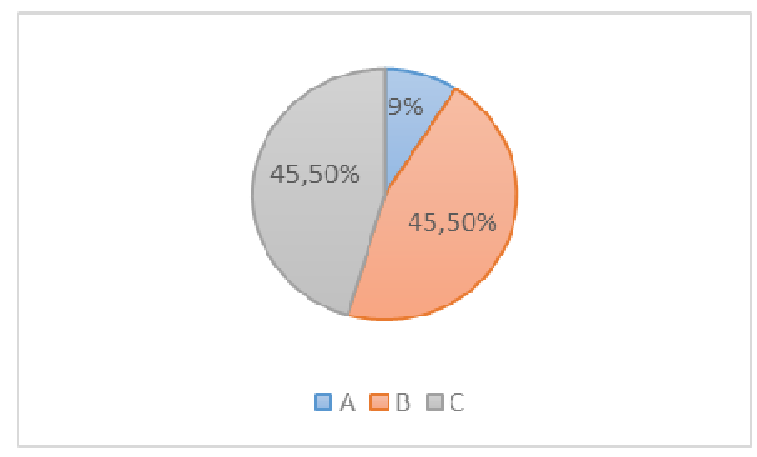

Fig 2. Presentasi of Acreditation in Elemantary School at Subulussalam City

Meanwhile, based on the calculation of the interval class length is 46,536. Furthermore, it can be divided into 3 categories: high, medium, and low categories. In the low category that is $\leq 97,536$, the medium category is $\leq 144,071$, and the high category is $\geq 144,072$. Table frequency of school quality as shown in Table 2.

TABLE 2. Table Frequency of School Quality Levels

\begin{tabular}{cccc}
\hline Category & Interval & Frequency & Percentage (\%) \\
\hline High & $144,072-190,606$ & 21 & 60 \\
\hline Medium & $97,536-144,071$ & 14 & 40 \\
\hline Low & $51,000-97,535$ & 0 & 0 \\
\hline
\end{tabular}

Based on Table 2 it can be seen that schools in the high category as much as $60 \%$, in the medium category as much as $40 \%$, and in the low category as much as $0 \%$. The results of calculating the average value for school quality variables are 151.720 , so when viewed from Table 2 the quality of schools is in the high category of $\geq 144,072$.

\section{B. Discussion}

Based on the results of the study it was found that out of the 11 schools studied the number of schools with an A accreditation status was 1 school or $9 \%$. The number of schools with B accreditation status is 5 schools or $45.5 \%$. Furthermore, the number of schools with $\mathrm{C}$ accreditation status is 5 schools or $45.5 \%$. All state elementary schools in Subulussalam city have attended school accreditation programs.

Furthermore, the school's performance is the quality of the values or the good and bad measures of the place of education or in this case the school.

Input is an external stimulus that is applied to a control system to obtain certain responses from the regulatory system According to [2] author, suggests that input includes the following aspects: (a) personnel consisting of principals, teachers, counselors, employees, and students, (b) material consisting of buildings and equipment, funds, materials, facilities; (c) operations consist of curriculum structure, regulations, job descriptions, mechanisms; (d) expectations consist of vision, mission, goals, objectives and policies.

Based on descriptive analysis per sub-variable quality, for sub-variables of school input are in the high category with an average number of 85.845 . Furthermore, when viewed from the percentage with a frequency of 22 schools or $63 \%$ of schools have high-school school inputs. This is consistent with the opinion of [5] that the expectation of high graduates must be supported by input, namely prospective students, education staff, non-educative employees, and quality learning facilities as well. Furthermore, according to [6] states that in an effort to improve the quality of education is certainly not free from the role of school principals, teachers, students, infrastructure.

The process is the activity of continuing learning in school. According to Soetopo [2] the process includes decision making, management, institutions, programs, teaching and learning processes, monitoring and evaluation. Based on descriptive analysis per sub variable quality, for the school process sub-variables are in the high category with an average number of 26,523. Furthermore, when viewed from the percentage with a frequency of 18 schools or $51 \%$ of schools have a high-school school process. This is consistent with the opinion of [5] that quality schools mean quality learning processes as well, in the sense of being efficient, relevant, and with high productivity.

Furthermore, according to [7] in an effective school there is an effective learning process, with the following characteristics: (a) active rather than passive; (b) invisible; (c) complicated rather than simple; (d) influenced by individual differences among students; and (e) influenced by various contexts. In general the school process has been regulated in the Minister of National Education Regulation No. 41 of 2007 for primary and secondary education units. While school management is regulated in the Minister of National Education Regulation No. 19 of 2005 concerning Education Management Standards by Primary and Secondary Education Units. In the learning process, students are situated in a learning atmosphere that ensures quality achievement. A quality process will produce quality students. According to [8] the quality of students is shown by among others, persistence, perseverance, discipline, power of innovation, creativity, capability, and responsibility.

Output is the actual response obtained from a control system. To be said to be a quality school, then 144 Education Management and Supervision, quality inputs and processes are needed, so they can produce quality output. Based on descriptive analysis per sub variable quality, for the school output sub variable is in the high category with A grade accreditation.

\section{CONCLUSION}

The results showed that there was a relationship between school accreditation status and school achievement performance. Public elementary schools in the Subulusalam city with $\mathrm{A}$ grade accreditation has much better quality than $\mathrm{B}$ 
accreditation, and $\mathrm{C}$ accreditation. And schools quality of primary with $\mathrm{B}$ accreditation is much better than $\mathrm{C}$ accreditation. Achievement of better school performance is based on the extent to which schools meet 8 national education standards

\section{SUGGESTION}

in this study are as follows: (1) The Principal of SD Negeri in Subulussalam Municipality, should pay more attention to the fulfillment of national education standards, especially in terms of completeness of documents related to the curriculum and meeting the needs of students such as the completeness of school facilities and infrastructure; (2) The Head of the Subulussalam City National Education Agency, should further enhance cooperation with schools in an effort to improve the quality of schools, such as improving the quality of school facilities and infrastructure and assistance to schools in preparing the completeness of school documents.

\section{REFERENCES}

[1] Muman...Kepemimpinan Kepala Sekolah”. Malang: UIN Maliki Advertisment, 2010, pp.216-217.

[2] Rakhiyah Ity, "Peningkatan Mutu Layanan Pendidikan Melalui Akreditasi Satuan Pendidikan”. UNJ, Jakarta Vol 14, No. 25, May 2018

[3] Education National Department, "Indonesia Constituty No 20 2003, about Education Nasional System”, Jakarta. Unpublished

[4] Fattah, Nanang. 2009. Landasan Manajemen Pendidikan. Bandung: Remaja Rosda Karya

[5] Susuri. "Pengaruh Akreditasi Sekolah Terhadap Peningkatan Mutu Pendidikan di SD se kota Bogor". Vol 8, No. 220 Mei 2018

[6] Almawadi. "Upaya Peningkatan Mutu Pendidikan Di Madrasah Aliyah Negeri Maguwoharjo Sleman Yogyakarta," UNY Journal, Indonesia, Vol 11, pp.706-712, November 2017.

[7] Sukmadinata, NS. Metode Penelitian Pendidikan. Bandung: Remaja Rosda Karya, 2006, pp. 89

[8] Sari, R. P. \& Wiyono, B. B. 2013. "Pengaruh Kualitas Pelayanan Sekolah terhadap Kepuasan Peserta Didik dan Orangtua Peserta Didik. Manajemen Pendidikan,” Vol 24, pp. 212-214, Sept 2013 